SHS Web of Conferences 17, 01010 (2015)

DOI: $10.1051 /$ shsconf $/ 20151701010$

(C) Owned by the authors, published by EDP Sciences, 2015

\title{
Credit Risk Analysis of Local Government Financing Platform - An empirical study based on KMV model
}

\author{
Tingting Zhou, Guangping Hui
}

School of Economics and Management, Nanjing University of Science and Technology, Nanjing, Jiangsu, China

\begin{abstract}
The local government financing platform is set up by local government through state-owned assets, real estate and equity capital. The functions of these companies are financing, construction, operation, the repaying debts. The local government financing platform can broaden the financing channels of local government in a great extent; alleviate the pressure of capital requirement. But at the same time, with the gradual expansion of the scale of debt, a series of problems has arisen: the amount of financing platform companies is huge, debt repayment depends too much on real estate price, the integration of government administration with enterprise, capital injection, and accounts of these companies are not well exposed. Once these problems outbreak, it may cause a series of financial crises, thereby threaten the entire banking industry even the healthy development of the national economy.
\end{abstract}

Keywords. local government financing platform; credit risk; KMV model

\section{Local government financing platform overview}

\subsection{The meaning of local government financing platform}

Financing platform of local government in China started in the 90's of last century, in 1992 Shanghai government established the Shanghai Urban Construction Investment Development Corporation, as the sign local government officially entered the "era of the city investment", The local government financing platform is established by the local government through state-owned assets, land and public debt, which performs financing function of local government in the financial market with independent legal personality, the operation of the project is public or semi public urban infrastructure construction. Local government financing platform loans have local government fiscal revenue and the government credit as guarantee.

\subsection{Types of local government financing platform}

Local government financing platform can be divided into public financing platform and business financing platform according to whether it can repay bank loans by its own operating cash flow. The public financing platform invests on public welfare projects that do not generate revenue or generate less income, which is not enough to pay the principal and interest of bank loans, such as 
urban bridges, roads, fitness facilities. Public financing platform needs local government fiscal support. Business financing platform finance construction projects that could generate income. This kind of financing platform is responsible for it own profit and loss, relying on the project operation income to repay the loan. The operation mode is same as the common enterprise; the only difference is that its founding capital relies on local government financial investment.

\section{Credit risk of local government financing platform loan}

According to the Audit Commission announcement in late 2013, "The National Government Debt Audit Report" data shows, by June 2013, China's local government debt has reached 10.89 trillion Yuan, compared to 9.63 trillion Yuan at the end of 2012, increased by $13.06 \%$ in just six months, the growth rate is extremely high. And in 2013 the national local government fiscal revenue amounted to only 6.90 trillion Yuan, only the equivalent of $63.36 \%$ existing debt. Such a huge scale of debt makes the local government fiscal crisis more and more serious. On the other hand, because of the long-term nature of the local government financing platform debt, many projects can not be completed and put into service during the official tenure, and is likely to turn into the "unfinished project", the arrears of old debts, new debt covers for old debt, all make it more difficult to solve the government financing platform loan repayment problem.

\section{An empirical study of credit risk of local government financing platform}

\subsection{Basic idea of KMV model}

The basic idea of KMV model is seeing the bank loan as buying a European call option. That is, when the enterprises obtain a loan from a commercial bank, it is equivalent to buying a European option, with enterprise assets market value being the underlying assets, loans of enterprises being the executive price, the term of the loan being the option period. It is the same as temporarily "transfer" the ownership of the enterprise to banks, but the enterprise can "redeem" its ownership through repaying the debt. On the due day of debt, if the market value of assets of the enterprise is higher than required repayment of the principal and interest of the loan, then the enterprise will choose to executive the option, namely to repay the debt and redeem the ownership of enterprises. On the contrary, if the market value of assets of the enterprise is less than the total amount of the debt, then enterprise will choose to abandon the option, default occurs. The central idea of the $\mathrm{KMV}$ model is that the changes in the market value of enterprise assets is the fundamental reason of the credit risk, if we can model the value of the assets, and find out the changes in the rule, we can calculate the expected default frequency (EDF) of the debts of the enterprise.

\subsection{Improvement on the KMV model}

Local government financing platform loans are different from ordinary business loans, the most important difference is that the market value of assets and their volatility of the local government financing platform can not be calculated directly according to the stock price and volatility like ordinary enterprises, so in the use of KMV model on the analysis of credit risk of local government financing platform, it is necessary to make corresponding improvement.

The basic idea of the KMV model applied to the problems of local government financing platform debt credit risk is as followed: the local government financing platform loan is viewed as local government revenue being temporarily "transferred" to the bank, on the due day of the debt, if the local government revenue is sufficient to cover the debt, local government financing platform will repay the loan and redeem the revenue; on the contrary, if the local government revenue is unable to cover the debt, default occurs. 
In summary, the KMV model is improved as followed: the asset market of enterprise valueis replaced by the local government revenue, the assets volatility of the enterprise value is replaced by the volatility of the local government revenue. andcan be obtained from the fiscal data of local governments of National Bureau of statistics.

The model assumes that the local government fiscal revenue follows the geometric Brown motion just like the market value of enterprise assets. When the debt is due, if (is the value of the debt, is the fiscal revenue), default occurs. In order to calculate the EDF of local government financing platform loans a year after, we assume in the empirical analysis that .According to the formula we can get:

$$
\begin{gathered}
g=\frac{1}{n-1} \sum_{t=1}^{n-1} \ln \frac{R_{t+1}}{R_{t}}+\frac{1}{2} \sigma_{R}^{2} \\
\sigma_{R}=\sqrt{\frac{1}{n-2} \sum_{t=1}^{n-1}\left(\ln \frac{R_{t+1}}{R_{t}}-\frac{1}{n-1} \sum_{t=1}^{n-1} \ln \frac{R_{t+1}}{R_{t}}\right)^{2}}
\end{gathered}
$$

And as the local government revenue obeys logarithmic normal distribution, so the default distance (DD) and default probability (EDF) can be expressed as:

$$
\begin{gathered}
D D=\frac{\ln \frac{R_{T}}{L_{T}}+\left(g-\frac{\sigma_{R}^{2}}{2}\right) T}{\sigma_{R} \sqrt{T}} \\
P=N\left[-\frac{\ln \frac{R_{T}}{L_{T}}+\left(g-\frac{\sigma_{R}^{2}}{2}\right) T}{\sigma_{R} \sqrt{T}}\right]
\end{gathered}
$$

In the formula, $R$ is the local government revenue, $g$ is local government fiscal revenue growth rate, $\sigma_{R}$ is local government fiscal revenue volatility.

\subsection{Empirical research of KMV model on financing platform credit risk of Jiangsu province}

\subsubsection{Data processing}

This paper selects the data of GDP, local fiscal revenue, local fiscal expenditure and infrastructure investment of Jiangsu province from 2003 to 2013 for the model analysis, all data comes from the annual statistical data of National Bureau of statistics.

There is a large number of spontaneous expenditure of local government finance income, regarding the total local government revenue as financing platform loan guarantee is not practical. On the basis of previous city infrastructure construction investment accounted for the proportion of local government expenditure, this paper chooses $30 \%$ as the government finance income proportion. In the following model analysis, the local government revenue is multiplied by $30 \%$, and then takes into calculation. 
Table1. 2003-2013 fiscal data of Jiangsu Province

\begin{tabular}{lllll}
\hline Year & GDP & Local fiscal revenue & Local fiscal expenditure & Infrastructure investment \\
\hline 2003 & 12442.87 & 798.11 & 1047.68 & 1418.33 \\
2004 & 15003.60 & 980.49 & 1312.04 & 1720.02 \\
2005 & 18598.69 & 1322.68 & 1673.40 & 1797.38 \\
2006 & 21742.05 & 1656.68 & 2013.25 & 1875.78 \\
2007 & 26018.48 & 2237.73 & 2553.72 & 1854.24 \\
2008 & 30981.98 & 2731.41 & 3247.49 & 2142.10 \\
2009 & 34457.30 & 3228.78 & 4017.36 & 3067.89 \\
2010 & 41425.48 & 4079.86 & 4914.06 & 3550.70 \\
2011 & 49110.27 & 5148.91 & 6221.72 & 3591.14 \\
2012 & 54058.22 & 5860.69 & 7027.67 & 4134.52 \\
2013 & 59161.75 & 6530.20 & & \\
\hline
\end{tabular}

\subsubsection{The calculation of the principal and interest of the loan}

In 2012, the total infrastructure investment of Jiangsu province is 413.45 billion Yuan, according to the proportion of capital for the fixed assets investment project requirements, we follow the minimum requirement of $30 \%$ to calculate, namely the highest financing proportion is $70 \%$. According to People's Bank of Chinese, the current loan interest rate over five years is $6.80 \%$, we can get the principal and interest of the local government financing platform loan of each financing ratio of Jiangsu province in 2013.

Table2. The 2013 local government financing platform loan of each ratio of Jiangsu province

\begin{tabular}{lll} 
& \multicolumn{1}{c}{ Unit: 100 million Yuan } \\
\hline Financing ratio (\%) & The amount of financing & The principal and interest of the loan in 2013 \\
\hline 10.00 & 413.45 & 441.57 \\
20.00 & 826.90 & 883.13 \\
30.00 & 1240.36 & 1324.70 \\
40.00 & 1653.81 & 1766.27 \\
50.00 & 2067.26 & 2207.83 \\
60.00 & 2480.71 & 2649.40 \\
70.00 & 2894.16 & 3090.97 \\
80.00 & 3307.62 & 3532.53 \\
\hline
\end{tabular}

\subsubsection{The calculation of EDF}

According to the formula1 and formula2, and, then take the local government revenue values into the calculation, we can get and .

Then take the values into formula3 and formula4, calculate the EDF of each financing ratio shown in Table3.

Table 3. EDF of each financing ratio

Unit:100 million Yuan

\begin{tabular}{lllll}
\hline $\begin{array}{l}\text { Financing } \\
\text { ratio (\%) }\end{array}$ & $\begin{array}{l}\text { The amount of } \\
\text { financing }\end{array}$ & $\begin{array}{l}\text { The principal and interest } \\
\text { of the loan in 2013 }\end{array}$ & DD & EDF \\
\hline 10.00 & 413.45 & 441.57 & 24.1786 & $1.8683 \mathrm{E}-129$ \\
20.00 & 826.90 & 883.13 & 13.9652 & $1.27095 \mathrm{E}-44$ \\
30.00 & 1240.36 & 1324.70 & 8.2502 & $7.90648 \mathrm{E}-17$ \\
40.00 & 1653.81 & 1766.27 & 4.3620 & $6.44394 \mathrm{E}-06$ \\
50.00 & 2067.26 & 2207.83 & 1.4646 & 0.071515041 \\
60.00 & 2480.71 & 2649.40 & -0.8135 & 0.792034277 \\
70.00 & 2894.16 & 3090.97 & -2.6695 & 0.996201786 \\
80.00 & 3307.62 & 3532.53 & -4.2210 & 0.999987839 \\
\hline
\end{tabular}




\subsubsection{Analysis of empirical conclusions}

From Table3 we can see, when the local government financial income guarantees for the loan with the financing ratio below $40 \%$, the default risk is negligible. When financing ratio exceeds $40 \%$, the default risk begins to increase, and when the ratio is more than $50 \%$, the risk of default will come to an exponential rise.

According to the international standard credit rating, corporate debt credit rating is regarded as a security level when it is more than The Standard \& Poor's credit level BBB or Moody's credit level Baa2. Conversion into expected default rate is $0.4 \%$, that is, the expected default rate of less than $0.4 \%$ of the debt is safe. According to the rating standard of the international credit rating agency and expected default frequency, we draw the conclusion: the safe scale of Jiangsu province local government financing platform loans should be controlled less than 165.38 billion Yuan, accounting for $28.22 \%$ of the fiscal revenue of Jiangsu province in 2012 , the loan principal and interest will account for $27.05 \%$ of the fiscal revenue of Jiangsu province in 2013.

\section{Suggestions}

The realization of standard operation of local government financing platform is a systematic work, it needs the cooperation of government, bank and financing platform. First of all, the government should reduce the local construction funds shortage problem from the angle of the system, and broaden the financing channels of local government. At the same time to reform the existing the government achievement evaluating and appraising system, and realize the scientific allocation of funds, the government should also improve the regulatory mechanism, implement a full range of management upon the operation of the financing platform.

Commercial banks should strengthen the financing platform loan scrutiny, and effectively improve the access threshold. In the loan application, the bank should not only have a comprehensive understanding of local financing platform, but also understand the local economic development and local government fiscal revenue and expenditure, government credit, debt and other information, then draw the final conclusion on interest rate and guarantee system. Banks should strengthen the inter-bank cooperation; encourage the exchange of information and communication.

The local government financing platform should establish modern corporate governance structure, and strengthen the management of loan funds. It can reduce the potential risk of debt through the establishment of a financing platform debt provision system. Provision should be set up according to the local government fiscal situation, to ensure that the public welfare projects whose income can not repay the loan can get plenty of sinking funds, thus be successfully completed and put into use. At the same time the local government financing platform should improve repayment mechanism, to prevent the credit risk to the largest extent.

\section{References}

1. Buchanan James. Public Principles of Public Debt [J]. Irwin. 1995(67): 98-102.

2. Sergei Shatalov, Hana Polackove Brixi, Leila Zlaoui. Managing Fiscal Fisk in Bulgaria [J]. The World Bank. 2001(16): 29-31.

3. Hana Polackova Brixi. Contingent Government Liabilities: A Hidden Risk for Fiscal Stability [J]. The World Bank. 1998(67): 39-45.

4. KMV. Credit Monitor Overview [M]. San Francisco: KMV Corporation. 1993.

5. Hana Polackova Brixi. Contingent Government Liabilities: A Hidden Risk for Fiscal Stability [M]. Washington DC: Policy Research Working Paper World Bank. 1998.

6. Hana Polackova Brixi, Allen Schick. Government at Risk: Contingent Liabilities and Fiscal Risk [M]. New York: The World Bank and Oxford University Press. 2002.

7. Allen Schick. Budgeting for Fiscal Risk [R]. The World Bank. 2000. 